\title{
AGRONOMIC BIOFORTIFICATION OF GREEN BEAN (PHASELOUS VULGARIS L.) WITH ELEMENTAL SULPHUR AND FARMYARD MANURE
}

\author{
ORMAN, Ș.*-KAPLAN, M. \\ Department of Soil Science and Plant Nutrition, Faculty of Agriculture, Akdeniz University \\ Antalya, Turkey \\ (phone: +90-242-310-6526; fax: +90-242-227-4564) \\ *Corresponding author \\ e-mail:suleorman@akdeniz.edu.tr \\ (Received $8^{\text {th }}$ Aug 2017; accepted $27^{\text {th }}$ Oct 2017)
}

\begin{abstract}
The effects of elemental sulphur and farmyard manure on agronomic biofortification within the parameters of N, P, S and N:S ratio were evaluated in green bean (Phaselous vulgaris $\mathrm{L}$.). Sulphur $0\left(\mathrm{~S}_{0}\right)$, $50\left(\mathrm{~S}_{1}\right), 100\left(\mathrm{~S}_{2}\right), 150\left(\mathrm{~S}_{3}\right), 200\left(\mathrm{~S}_{4}\right), 400\left(\mathrm{~S}_{5}\right) \mathrm{mg} \mathrm{kg}^{-1}$ and farmyard manure $0\left(\mathrm{FYM}_{0}\right), 3\left(\mathrm{FYM}_{1}\right)$ tonnes $\mathrm{da}^{-1}$ were applied to a calcareous sandy loam soil with low organic matter and sulphur deficient. Three weeks after the applications, bean seeds were sown in pot soils and after eight weeks of growing period the shoots were harvested. The soil $\mathrm{pH}$ was decreased while EC was increased by the applications of $\mathrm{S}$ and FYM. The P concentration of shoot was increased by S with FYM. While the dry weight and S concentration of shoot were increased, $\mathrm{N}$ concentration was slightly decreased by $\mathrm{S}$, alone. The $\mathrm{N}: \mathrm{S}$ ratio decreased from 23.76 in $\mathrm{S}_{0} \mathrm{FYM}_{0}$ to 15.93 in $\mathrm{S}_{5} \mathrm{FYM}_{1}$. All results indicate that sulphur applications in $\mathrm{S}_{1}$ and $\mathrm{S}_{2}$ levels with farmyard manure can be sufficient for growing bean in the soil.
\end{abstract}

Keywords: malnutrition, chemical fertilizer, organic manure, nitrogen, phosphorus

\section{Introduction}

Two thirds of the world population faces with one or more essential mineral deficiencies in their nutrition. Solutions to this problem are being investigated by means of dietary diversification, mineral adding, food supplements or increasing bioavailability and concentrations of mineral elements during crop production. Especially there have been recent studies on plants which have an essential importance in human nutrition with agronomic and genetic biofortification. Agronomic biofortification tries to ensure the optimization of mineral fertilizer applications and improving of mineral element mobility and solubility in soil. The optimization of chemical fertilizer and organic manure applications or the applications of essential elements with enriched fertilizer (especially NPK fertilizers) throughout soil, leaf or seed during cultivation should not only provide a quick solution in human and animal nutrition but also will be a complementary approach for ongoing plant breeding programme.

Sulphur is one of the essential elements in plant growth. Plants need sulphur for protein synthesis, chlorophyll, oil and vitamin formation. Sulphur deficiency has a negative effect on both yield and quality of crops which are grown for human and animal consumption (Tiwari et al., 1997). The specific aim of most biofortification studies is to reduce mineral, vitamin and protein deficiencies in edible parts of plants. Sulphur takes role in synthesis of some compounds such as cysteine, cystine and methionine for protein formation in plants. Low sulphur content in proteins is a nutritionally adverse situation and the methionine which is the main source of protein 
and can be synthesized in the presence of sulphur is a basic amino acid for human nutrition.

Sulphate absorbed by the roots is the most important source of sulphur. Despite the sulphur's distribution on all parts of soil profile, it has at its highest concentration on surface soil which is rich in organic matter. Sandy or low organic content soils are the ones which are encountered with sulphur deficiency. On the situations of high efficiency on crop yield, especially on sandy soils and soils that are poor in organic matter which has abundant watering, the sulphur content is not in sufficient quantity for the needs of plants (Anonymous, 1982). The sulphur deficiency in plants can also occur on coarse textured soils having a high $\mathrm{pH}$ and when there is insufficient moisture on their root zone (Tiwari, 1995). And also the sulphur deficiency usually occurs on cultivation areas where chemical fertilizers are used and of the plants that are in highly need of sulphur due to their high yield capacity. Therefore, in addition to nutrients such as $\mathrm{N}, \mathrm{P}_{2} \mathrm{O}_{5}$ and $\mathrm{K}_{2} \mathrm{O}$, S which is also named as the fourth basic macro nutrient should also be considered while doing fertilization programmes.

Bean is not only a product of high nutritional value, but also is an important vegetable protein source for humans. It has been widely consumed in Turkey and in Asian, African, European, North, South and Central American countries. For this reason, it is essential that it takes an important role among plants which are to be studied for increase yield and nutritive value. In this study, the effect of sulphur and farmyard manure applications on calcareous sandy loam soil having a low-sulphur and organic matter content for agronomic biofortification in bean is being examined using parameters of $\mathrm{N}, \mathrm{P}, \mathrm{S}$ and $\mathrm{N}: \mathrm{S}$.

\section{Material and methods}

\section{Experimental setup}

Soil was air dried and passed through a $4 \mathrm{~mm}$ sieve. A total of $9 \mathrm{~kg}$ of sieved soil was placed in pots with holes at the bottom. Sulphur $\left(S_{0}: 0, S_{1}: 50, S_{2}: 100, S_{3}: 150\right.$, $\left.\mathrm{S}_{4}: 200, \mathrm{~S}_{5}: 400 \mathrm{mg} \mathrm{kg}^{-1}\right)$ without farmyard manure $\left(\mathrm{FYM}_{0}: 0\right.$ tonnes $\left.\mathrm{da}^{-1}\right)$ and with farmyard manure $\left(\mathrm{FYM}_{1}: 3\right.$ tonnes $\left.\mathrm{da}^{-1}\right)$ was applied to soil according to completely randomized design factorial with 4 replicates. At the time of the application materials were mixed to soil, soil samples were taken at $1^{\text {st }}$ sampling period. Then, basal fertilization (as $8 \mathrm{~kg} \mathrm{~N} \mathrm{da}^{-1}, 8 \mathrm{~kg} \mathrm{P}_{2} \mathrm{O}_{5} \mathrm{da}^{-1}$ and $8 \mathrm{~kg} \mathrm{~K}_{2} \mathrm{O} \mathrm{da}^{-1}$ ) using 15.15 .15 fertilizer was made to each pot soil. Each pot was equally watered and incubated for 3 weeks. The green bean 'Öz Ayşe' was used as an experimental plant. At the end of the 3 weeks, $2^{\text {nd }}$ period soil samples were taken and four green bean seeds were sown in each pot soil. After the seeds germination, one bean plant was left in per pot and the plants were grown for 8 weeks. During the vegetation period, $\mathrm{N} 8.5 \mathrm{~kg} \mathrm{da}^{-1}\left(\mathrm{NH}_{4} \mathrm{NO}_{3}, 33 \% \mathrm{~N}\right)$, $\mathrm{P}_{2} \mathrm{O}_{5} 3.7 \mathrm{~kg} \mathrm{da}^{-1}$ (MAP), $\mathrm{K}_{2} \mathrm{O} 10 \mathrm{~kg} \mathrm{da}^{-1}\left(\mathrm{KNO}_{3}\right), \mathrm{MgO} 0.62 \mathrm{~kg} \mathrm{da}^{-1}\left(\mathrm{MgNO}_{3}\right)$ and 1.73 $\mathrm{kg}$ microelement fertilizer $\mathrm{da}^{-1}$ (Hortrilon, $5 \% \mathrm{Fe}, 2.5 \% \mathrm{Mn}, 0.5 \% \mathrm{Zn}, 2.5 \% \mathrm{Cu}$ ) were applied to each pot as fertilizer solution. At the end of the experiment, the shoots were harvested and $3^{\text {rd }}$ period soil samples were taken from each pot.

\section{Plant analysis}

The shoots were washed with deionized water and then dried $65 \mathrm{C}$ for $72 \mathrm{~h}$ to determine dry weight. The dried shoots were ground in a stainless steel mill which 
enabled them to be passed through a 20 mesh screen. The samples of $0.5 \mathrm{~g}$ each were digested with $10 \mathrm{~mL} \mathrm{HNO}_{3}$ and $\mathrm{HClO}_{4}$ (4:1) acid mixture on a hot plate and filtered and then, diluted to $100 \mathrm{~mL}$ using distilled water. Total $\mathrm{S}$ was conducted by the turbidimetric method with $\mathrm{BaCl}_{2} \cdot 2 \mathrm{H}_{2} \mathrm{O}$ and the readings were taken using a spectrophotometer at $430 \mathrm{~nm}$ (Kacar and Inal, 2008). Total $\mathrm{P}$ was measured by a modified colorimetric molybdo-vanado-phosphate method using a spectrophotometer at $430 \mathrm{~nm}$ (Kacar and Inal, 2008). Total $\mathrm{N}$ was determined by a modified Kjeldahl procedure (Kacar and Inal, 2008).

\section{Soil analysis}

The soil samples were air-dried and passed through a $2 \mathrm{~mm}$ sieve. The $\mathrm{pH}$ was measured in $\mathrm{H}_{2} \mathrm{O}$ (1:2.5 soil:deionized water) and the electrical conductivity (EC) value was determined directly on the saturation paste. The soil particle size analysis was done by using the hydrometer method (Bouyoucos, 1955) and the $\mathrm{CaCO}_{3}$ content was determined by using a Scheibler calcimeter. Organic matter was determined by using modified Walkley-Black procedure (Black, 1965). The total nitrogen was done by using modified Kjeldahl procedure (Kacar, 2009). Available $\mathrm{P}$ was extracted by $\mathrm{NaHCO}_{3}$ and determined by a molybdate colorimetric method (Olsen and Sommers, 1982). Soil samples were extracted for $\mathrm{SO}_{4}-\mathrm{S}$ by using $500 \mathrm{mg} \mathrm{kg}^{-1} \mathrm{P}$ as $\mathrm{KH}_{2} \mathrm{PO}_{4}$ which contents of Fox et al. (1964). Analyses were conducted by the turbidimetric method with $\mathrm{BaCl}_{2} \cdot 2 \mathrm{H}_{2} \mathrm{O}$ and the readings were taken using a spectrophotometer at $430 \mathrm{~nm}$ (Kacar, 2009). Some of the physical and chemical properties of experiment soil were given in Table 1 .

Table 1. Physical and chemical properties of soil used

\begin{tabular}{c|c}
\hline Parameter & Soil \\
\hline Sand (\%) & 63.52 \\
Clay (\%) & 18.48 \\
Silt (\%) & 18 \\
Texture & Sandy loam \\
$\mathrm{pH}$ & 7.80 \\
$\mathrm{CaCO}_{3}(\%)$ & 18.92 \\
$\mathrm{EC}\left(\mathrm{dS} \mathrm{m} \mathrm{m}^{-1}\right)$ & 2.07 \\
Organic matter $(\%)$ & 2.27 \\
Total N $(\%)$ & 0.049 \\
Available-P $\left(\mathrm{mg} \mathrm{kg}^{-1}\right)$ & 34.57 \\
Extractable-SO & $-{\mathrm{S}\left(\mathrm{mg} \mathrm{kg}^{-1}\right)}$ \\
\hline
\end{tabular}

\section{Statistical analysis}

The data were analyzed by standard ANOVA procedures and their significances were always based on the $P<0.05$ level using the LSD tests. 


\section{Results and discussion}

\section{Effects of sulphur and farmyard manure on soil pH and EC}

In the $1^{\text {st }}$ soil sampling period, the farmyard manure caused an important but little increase of 0.03 units on soil $\mathrm{pH}$. In the $2^{\text {nd }}$ and $3^{\text {rd }}$ soil sampling periods, the effects of interactions of sulphur and farmyard manure on soil $\mathrm{pH}$ were found significant. In the $2^{\text {nd }}$ sampling period, the highest decrease on soil $\mathrm{pH}$ was respectively obtained as 7.65 and 7.64 in applications of $\mathrm{S}_{5} \mathrm{FYM}_{0}$ ve $\mathrm{S}_{5} \mathrm{FYM}_{1}$. When the sulphur applications whether with or without farmyard manure compared, the applications of $\mathrm{S}_{0} \mathrm{FYM}_{0}$ and $\mathrm{S}_{0} \mathrm{FYM} \mathrm{M}_{1}$, $\mathrm{S}_{2} \mathrm{FYM}_{0}$ and $\mathrm{S}_{2} \mathrm{FYM}_{1}, \mathrm{~S}_{4} \mathrm{FYM}_{0}$ and $\mathrm{S}_{4} \mathrm{FYM}_{1}$ differed from each other and in these applications, soil $\mathrm{pH}$ was determined to be a little bit lower when sulphur is applied with farmyard manure. And in the $3^{\text {rd }}$ soil sampling periods, the highest decrease on soil $\mathrm{pH}$ was respectively obtained as 7.70 and 7.76 in applications of $\mathrm{S}_{5} \mathrm{FYM}_{0}$ and $\mathrm{S}_{5} \mathrm{FYM}_{1}$. When the sulphur applications with or without farmyard manure compared, $\mathrm{S}_{2} \mathrm{FYM}_{0}$ and $\mathrm{S}_{2} \mathrm{FYM}_{1}, \mathrm{~S}_{5} \mathrm{FYM}_{0}$ and $\mathrm{S}_{5} \mathrm{FYM}_{1}$ differed from each other and in these applications, a little increase in soil $\mathrm{pH}$ was obtained when sulphur is applied with farmyard manure. In an overall evaluation, especially in the $2^{\text {nd }}$ sampling period (after three weeks from applications) depending on irrigation, the $\mathrm{pH}$ of control soil $\left(\mathrm{S}_{0} \mathrm{FYM}_{0}\right)$ rose from 7.81 up to 8.01, whereas no increase in sulphur with farmyard manure applications was observed. Almost similar effects of the applications were determined in the $3^{\text {rd }}$ sampling period (Table 2). Kaplan and Orman (1998) reported that the sulphur applied to high calcareous soil decreased $\mathrm{pH}$ in units of $0.07-0.35$ and the $\mathrm{pH}$ started to rise again depending on time.

Table 2. Effects of sulphur (S) and farmyard manure (FYM) on soil pH

\begin{tabular}{|c|c|c|c|c|c|c|c|c|c|}
\hline \multirow{3}{*}{$\begin{array}{c}\text { Sulphur } \\
\text { doses }\end{array}$} & \multicolumn{9}{|c|}{ Soil pH } \\
\hline & \multicolumn{3}{|c|}{$1^{\text {st }}$ soil sampling } & \multicolumn{3}{|c|}{$2^{\text {nd }}$ soil sampling } & \multicolumn{3}{|c|}{$3^{\text {rd }}$ soil sampling } \\
\hline & FYM $_{0}$ & FYM $_{1}$ & Means & FYM $_{0}$ & FYM $_{1}$ & Means & $\mathrm{FYM}_{\mathbf{0}}$ & $\mathrm{FYM}_{1}$ & Means \\
\hline $\mathrm{S}_{0}$ & 7.81 & 7.83 & 7.82 & $8.01 \mathrm{a}^{(\mathbf{1})}, \mathbf{A}$ & $7.88 \mathrm{a}, \mathbf{B}$ & 7.95 & $7.89 \mathrm{a}, \mathbf{A}$ & $7.90 \mathrm{a}, \mathbf{A}$ & 7.89 \\
\hline $\mathrm{S}_{1}$ & 7.85 & 7.86 & 7.85 & $7.83 \mathrm{~b}, \mathbf{A}$ & $7.85 \mathrm{a}, \mathbf{A}$ & 7.84 & $7.81 \mathrm{~b}, \mathbf{A}$ & $7.83 \mathrm{~b}, \mathbf{A}$ & 7.82 \\
\hline $\mathrm{S}_{2}$ & 7.83 & 7.87 & 7.85 & $7.83 \mathrm{~b}, \mathbf{A}$ & $7.74 \mathrm{~b}, \mathbf{B}$ & 7.79 & $7.77 \mathrm{c}, \mathbf{B}$ & $7.80 \mathrm{c}, \mathbf{A}$ & 7.78 \\
\hline $\mathrm{S}_{3}$ & 7.81 & 7.87 & 7.84 & $7.74 \mathrm{c}, \mathbf{A}$ & $7.75 \mathrm{~b}, \mathbf{A}$ & 7.75 & $7.78 \mathrm{c}, \mathbf{A}$ & $7.79 \mathrm{c}, \mathbf{A}$ & 7.78 \\
\hline $\mathrm{S}_{4}$ & 7.83 & 7.85 & 7.84 & $7.76 \mathrm{c}, \mathbf{A}$ & $7.72 \mathrm{~b}, \mathbf{B}$ & 7.74 & $7.76 \mathrm{c}, \mathbf{A}$ & $7.75 \mathrm{~d}, \mathbf{A}$ & 7.76 \\
\hline $\mathrm{S}_{5}$ & 7.83 & 7.87 & 7.85 & $7.65 \mathrm{~d}, \mathbf{A}$ & $7.64 \mathrm{c}, \mathbf{A}$ & 7.64 & $7.70 \mathrm{~d}, \mathbf{B}$ & $7.76 \mathrm{~d}, \mathbf{A}$ & 7.73 \\
\hline Means & $7.83 \mathbf{B}^{(2)}$ & $7.86 \mathbf{A}$ & & 7.80 & 7.76 & & 7.78 & 7.80 & \\
\hline \multicolumn{10}{|c|}{$\mathrm{ANOVA}^{(3)}$} \\
\hline $\mathrm{S}$ & \multicolumn{3}{|c|}{ n.s. } & \multicolumn{3}{|c|}{$* *$} & \multicolumn{3}{|c|}{$* *$} \\
\hline FYM & \multicolumn{3}{|c|}{$* *$} & \multicolumn{3}{|c|}{$* *$} & \multicolumn{3}{|c|}{$* *$} \\
\hline S*FYM & \multicolumn{3}{|c|}{ n.s. } & \multicolumn{3}{|c|}{$* *$} & \multicolumn{3}{|c|}{$*$} \\
\hline
\end{tabular}

${ }^{(1)}$ Means in the same column followed by the same letter are not significantly different at $5 \%$ probability level by LSD test; ${ }^{(2)}$ Means in the same row followed by the capital and bold same letter are not significantly different at $5 \%$ probability level by LSD test; ${ }^{(3)}$ Significance levels: ${ }^{*} \mathrm{p}<0.05 ; * * \mathrm{p}<0.01$; n.s.: non significant

In the $1^{\text {st }}$ soil sampling period, the effects of sulphur on soil EC was not significant whereas the farmyard manure effect was important. While the soil EC was highly affected from the sulphur and farmyard manure in the $2^{\text {nd }}$ and $3^{\text {rd }}$ sampling periods, the 
interaction between these two applications was not significant in each three sampling periods. The farmyard manure caused an increase about $0.29,0.37$ and 0.29 units in soil EC, respectively in the $1^{\text {st }}, 2^{\text {nd }}$ and $3^{\text {rd }}$ sampling periods. The sulphur yet caused an increase on soil EC only in the $2^{\text {nd }}$ and $3^{\text {rd }}$ sampling periods and the highest increase of EC was observed in $\mathrm{S}_{4}$ and $\mathrm{S}_{5}$ (Table 3). The sulphur applications are reported to cause an increase in soil salinity in several studies (Modaish et al., 1989; Kaplan and Orman, 1998; Orman and Kaplan, 2011; Orman and Ok, 2012). And also in this study, it has been indicated that especially the sulphur applications increases the soil salinity significantly. It is thought that this is because of the $\mathrm{SO}_{4}{ }^{-2}$ having been formed in soil after the sulphur applications and also because of irrigation and fertilization during the growing period. Thus, a significantly positive correlation between $\mathrm{EC}$ values and $\mathrm{SO}_{4}{ }^{-2}-$ $S$ concentrations of greenhouse soils where tomato cultivation is made in West Mediterranean Region has been reported by Orman and Kaplan (2009).

Table 3. Effects of sulphur (S) and farmyard manure (FYM) on soil EC

\begin{tabular}{|c|c|c|c|c|c|c|c|c|c|}
\hline \multirow{3}{*}{$\begin{array}{c}\text { Sulphur } \\
\text { doses }\end{array}$} & \multicolumn{9}{|c|}{ Soil EC $\left(\mathrm{dS} \mathrm{m}^{-1}\right)$} \\
\hline & \multicolumn{3}{|c|}{$1^{\text {st }}$ soil sampling } & \multicolumn{3}{|c|}{$2^{\text {nd }}$ soil sampling } & \multicolumn{3}{|c|}{$3^{\text {rd }}$ soil sampling } \\
\hline & $\mathrm{FYM}_{0}$ & FYM $_{1}$ & Means & FYM $_{0}$ & FYM $_{1}$ & Means & $\mathrm{FYM}_{0}$ & FYM $_{1}$ & Means \\
\hline $\mathrm{S}_{0}$ & 2.10 & 2.33 & 2.22 & 4.35 & 5.01 & $4.68 c^{(1)}$ & 3.45 & 3.61 & $3.53 \mathrm{~d}$ \\
\hline $\mathrm{S}_{1}$ & 2.26 & 2.55 & 2.41 & 5.20 & 5.85 & $5.52 \mathrm{~b}$ & 4.05 & 4.05 & $4.05 \mathrm{c}$ \\
\hline $\mathrm{S}_{2}$ & 2.25 & 2.50 & 2.38 & 5.26 & 5.61 & $5.44 \mathrm{~b}$ & 4.26 & 4.32 & $4.29 \mathrm{bc}$ \\
\hline $\mathrm{S}_{3}$ & 2.13 & 2.49 & 2.31 & 5.34 & 5.55 & $5.44 \mathrm{~b}$ & 4.07 & 4.26 & $4.16 \mathrm{c}$ \\
\hline $\mathrm{S}_{4}$ & 2.20 & 2.55 & 2.37 & 5.77 & 6.23 & $6.00 \mathrm{a}$ & 4.07 & 5.00 & $4.53 \mathrm{ab}$ \\
\hline $\mathrm{S}_{5}$ & 2.17 & 2.49 & 2.33 & 6.43 & 6.34 & $6.38 \mathrm{a}$ & 4.64 & 5.02 & $4.83 \mathrm{a}$ \\
\hline Means & $2.22 \mathbf{B}^{(2)}$ & $2.48 \mathrm{~A}$ & & $5.39 \mathrm{~B}$ & $5.76 \mathrm{~A}$ & & $4.09 \mathrm{~B}$ & $4.38 \mathbf{A}$ & \\
\hline \multicolumn{10}{|l|}{$\mathrm{ANOVA}^{(3)}$} \\
\hline $\mathrm{S}$ & \multicolumn{3}{|c|}{ n.s. } & \multicolumn{3}{|c|}{$* *$} & \multicolumn{3}{|c|}{$* *$} \\
\hline FYM & \multicolumn{3}{|c|}{$* *$} & \multicolumn{3}{|c|}{$* *$} & \multicolumn{3}{|c|}{$* *$} \\
\hline $\mathrm{S} * \mathrm{FYM}$ & \multicolumn{3}{|c|}{ n.s. } & \multicolumn{3}{|c|}{ n.s. } & \multicolumn{3}{|c|}{ n.s. } \\
\hline
\end{tabular}

${ }^{(1)}$ Means in the same column followed by the same letter are not significantly different at $5 \%$ probability level by LSD test; ${ }^{(2)}$ Means in the same row followed by the capital and bold same letter are not significantly different at $5 \%$ probability level by LSD test; ${ }^{(3)}$ Significance levels: $* * p<0.01$; n.s.: non significant

\section{Effects of sulphur and farmyard manure on bean plant}

The effects of applications on total nitrogen, sulphur, and phosphorus concentrations, $\mathrm{N}: \mathrm{S}$ ratio and dry weight in the shoots of bean were given in Table 4.

The sulphur alone is found important to have a significant effect on nitrogen concentration in shoots an especially in higher doses of $100 \mathrm{mg} \mathrm{S} \mathrm{kg}^{-1}$, there has been a reduction in nitrogen concentration. Schung (1990) specified that the increase of $S$ content in plant tissues with suitable sulphur fertilization in vegetables had been effective in decrease of $\mathrm{NO}_{3}$ content in tissues. It was reported that sulphur applied to soil has no significant effect on nitrogen concentration in tomato plant, but the $\mathrm{N}$ concentration is observed to be lower than the control (Orman and Kaplan, 2011). Gaines and Phatak (1982) reported that with the increase of the sulphur ratio applied to soybean grown in hydroponic culture, the $\mathrm{N}$ concentration decreased in a significant 
rate. In our study, the decrease in nitrogen concentrations of bean shoots by the sulphur applications can either be related with sulphur and nitrogen relationships, or just arise due to the dilution effect of nitrogen in result of dry weight increase by sulphur.

Table 4. Effects of sulphur (S) and farmyard manure (FYM) on shoot N, S, P concentrations, $N: S$ ratio and dry weight

\begin{tabular}{|c|c|c|c|c|c|c|c|c|c|c|c|c|c|c|c|}
\hline \multirow{2}{*}{ 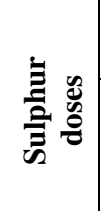 } & \multicolumn{3}{|c|}{$\mathbf{N}(\%)$} & \multicolumn{3}{|c|}{$\mathbf{S}(\%)$} & \multicolumn{3}{|c|}{$\mathbf{P}(\%)$} & \multicolumn{3}{|c|}{$\mathrm{N}: \mathrm{S}$} & \multicolumn{3}{|c|}{$\begin{array}{c}\text { Dry weight } \\
\left(\text { g pot }^{-1}\right)\end{array}$} \\
\hline & $\sum_{i}^{0}$ & $\sum_{\Sigma}^{\bar{\lambda}}$ & 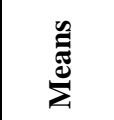 & $\sum_{i}^{e}$ & $\sum_{\Sigma}^{\bar{\lambda}}$ & 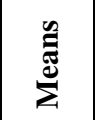 & $\sum_{i}^{0}$ & $\sum_{i}^{-J}$ & 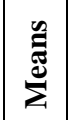 & $\sum_{i}^{0}$ & $\sum_{i}^{j}$ & 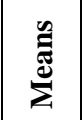 & $\sum_{i}^{0}$ & $\sum_{i}^{\bar{\lambda}}$ & 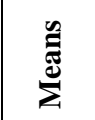 \\
\hline $\mathrm{S}_{0}$ & 3.24 & 3.22 & $3.23 \mathrm{ab}^{(1)}$ & 0.14 & 0.17 & $0.16 \mathrm{c}$ & $0.28 \mathrm{c}, \mathbf{B}^{(2)}$ & $0.32 \mathrm{a}, \mathbf{A}$ & 0.30 & 23.76a,A & $18.72 \mathrm{bc}, \mathbf{B}$ & 21.24 & 21.56 & 23.01 & $22.28 b$ \\
\hline $\mathrm{S}_{1}$ & 3.30 & 3.25 & $3.27 \mathrm{ab}$ & 0.17 & 0.17 & $0.17 \mathrm{bc}$ & 0.34a,A & $0.33 \mathrm{a}, \mathbf{A}$ & 0.33 & $19.87 \mathrm{~b}, \mathbf{A}$ & $19.82 \mathrm{~b}, \mathbf{A}$ & 19.84 & 28.61 & 28.54 & $28.57 \mathrm{a}$ \\
\hline $\mathrm{S}_{2}$ & 3.42 & 3.33 & $3.37 \mathrm{a}$ & 0.19 & 0.19 & $0.19 \mathrm{a}$ & $0.31 \mathrm{~b}, \mathbf{B}$ & $0.34 \mathrm{a}, \mathbf{A}$ & 0.33 & $18.83 \mathrm{bc}, \mathbf{A}$ & $17.25 \mathrm{bcd}, \mathbf{A}$ & 18.04 & 28.76 & 24.72 & $26.74 \mathrm{a}$ \\
\hline $\mathrm{S}_{3}$ & 3.00 & 3.22 & $3.11 \mathrm{~b}$ & 0.18 & 0.17 & $0.18 \mathrm{ab}$ & $0.31 \mathrm{~b}, \mathbf{A}$ & $0.32 \mathrm{a}, \mathbf{A}$ & 0.32 & $16.53 \mathrm{~cd}, \mathrm{~A}$ & $19.03 \mathrm{bc}, \mathbf{A}$ & 17.78 & 27.17 & 28.99 & $28.08 \mathrm{a}$ \\
\hline $\mathrm{S}_{4}$ & 3.12 & 3.27 & $3.20 \mathrm{ab}$ & 0.19 & 0.19 & $0.19 \mathrm{a}$ & $0.33 \mathrm{ab}, \mathbf{A}$ & $0.33 \mathrm{a}, \mathbf{A}$ & 0.33 & $16.63 \mathrm{~cd}, \mathrm{~A}$ & $17.22 \mathrm{bcd}, \mathbf{A}$ & 16.93 & 26.13 & 27.44 & $26.78 \mathrm{a}$ \\
\hline $\mathrm{S}_{5}$ & 3.15 & 3.09 & $3.12 b$ & 0.19 & 0.20 & $0.19 \mathrm{a}$ & $0.35 \mathrm{a}, \mathbf{A}$ & $0.33 \mathrm{a}, \mathbf{A}$ & 0.34 & $16.85 \mathrm{~cd}, \mathbf{A}$ & 15.93d,A & 16.39 & 27.36 & 27.96 & $27.66 \mathrm{a}$ \\
\hline Means & 3.20 & 3.23 & & 0.17 & 0.18 & & 0.32 & 0.33 & & 18.74 & 17.99 & & 26.60 & 26.78 & \\
\hline \multicolumn{16}{|c|}{ ANOVA $^{(3)}$} \\
\hline $\mathrm{S}$ & & \multicolumn{2}{|r|}{$*$} & \multicolumn{3}{|c|}{$* *$} & \multicolumn{3}{|c|}{$* *$} & \multicolumn{3}{|c|}{$* * *$} & \multicolumn{3}{|c|}{$* *$} \\
\hline FYM & & \multicolumn{2}{|c|}{ n.s. } & \multicolumn{3}{|c|}{ n.s. } & \multicolumn{3}{|c|}{$*$} & \multicolumn{3}{|c|}{ n.s. } & \multicolumn{3}{|c|}{ n.s. } \\
\hline $\mathrm{S} * \mathrm{FYN}$ & & \multicolumn{2}{|c|}{ n.s. } & \multicolumn{3}{|c|}{ n.s. } & \multicolumn{3}{|c|}{$* *$} & \multicolumn{3}{|c|}{$* *$} & \multicolumn{3}{|c|}{ n.s. } \\
\hline
\end{tabular}

${ }^{(1)}$ Means in the same column followed by the same letter are not significantly different at $5 \%$ probability level by LSD test; ${ }^{(2)}$ Means in the same row followed by the capital and bold same letter are not significantly different at $5 \%$ probability level by LSD test; ${ }^{(3)}$ Significance levels: $* * \mathrm{p}<0.01$; n.s.: non significant

The sulphur, farmyard manure and sulphur with farmyard manure interaction had a great impact on shoot phosphorus concentration. The shoot phosphorus concentration is determined as $0.28 \%$ in $\mathrm{S}_{0} \mathrm{FYM}_{0}$ whereas it is seen as $0.35 \%$ in $\mathrm{S}_{5} \mathrm{FYM}_{0}$. Having been evaluated with or without farmyard manure, the applications of $\mathrm{S}_{0} \mathrm{FYM}_{0}$ and $\mathrm{S}_{0} \mathrm{FYM} \mathrm{M}_{1}$, $\mathrm{S}_{2} \mathrm{FYM}_{0}$ and $\mathrm{S}_{2} \mathrm{FYM}_{1}$ differed from each other statistically and in these applications, applying sulphur with farmyard manure caused an increase in shoot phosphorus concentration. Also, it is thought that shoot phosphorus concentration increases due to the decrease in soil $\mathrm{pH}$ because of consequent sulphur applications. Brahim et al. (2017) indicated that the combined application of rock phosphate and elemental sulphur was the potential to improve the $\mathrm{P}$ nutrition of soybean.

The applications of sulphur alone significantly affected on shoot sulphur concentration. There has been an increase between $5.9 \%$ and $15.79 \%$ in shoot sulphur concentration according to the $S_{0}$. This impact is especially determined in $100 \mathrm{mg} \mathrm{S} \mathrm{kg}^{-1}$ level. Even though the shoot sulphur concentration has an increase about $5.56 \%$ by farmyard manure application, this impact is not found important statistically. Tiecher et al. (2012) observed that the amount of S accumulated in the shoots of sunflower, bean, soybean and castor bean and the level of available $\mathrm{S}$ increased due to $\mathrm{S}$ fertilization.

Reuther and Robinson (1998) notified that bean plant in early stage has a sufficient $S$ content of $0.16 \%-0.64 \%$ in shoots. The sulphur concentrations of shoots in our study range from $0.14 \%$ to $0.20 \%$. According to the limit values, it is significantly output that 
there has been an improvement in sulphur nutrition level of bean, especially as a result of sulphur applications.

The sulphur alone and sulphur with farmyard manure applications were significantly affected on total $\mathrm{N}$ : total $\mathrm{S}$ ratio of shoot. The N:S ratio in shoot is assigned as 23.76 in $\mathrm{S}_{0} \mathrm{FYM}_{0}$ and 18.72 in $\mathrm{S}_{0} \mathrm{FYM}_{1}$ and it showed statistically significant differences. The other applications of sulphur with or without farmyard manure were statistically included in the same group. The highest ratio of $\mathrm{N}: \mathrm{S}$ was determined in $\mathrm{S}_{0} \mathrm{FYM}_{0}$ application and the lowest of that was in $\mathrm{S}_{5} \mathrm{FYM}_{1}$ application. The shoot $\mathrm{N}: \mathrm{S}$ ratio showed a significant reduction especially as a result of sulphur alone applications. Barczak and Nowak (2015) reported that the potato plants fertilised with sulphur, in comparison with the control, N:S ratio was narrowed due to a higher increase in the content of sulphur rather than nitrogen in potato tubers.

Although it has been obtained that the effects of sulphur with farmyard manure has a great role on the shoots $\mathrm{N}: \mathrm{S}$ ratio, it is thought that the determining factor in the decline of this ratio is the sulphur applications. Total N: Total $\mathrm{S}$ ratio of the leguminous for protein synthesis is reported to be 17 (Kacar and Katkat 2007). It is pointed out by Stewart and Porter (1969) that the sulphur deficiency may be limiting in protein formation in case of the total N:total S ratio's being over 16 and it is just a severe sulphur deficiency in case of the ratio's being over 20 or more. The soil $\mathrm{SO}_{4}{ }^{-2}-\mathrm{S}$ concentration below $10 \mathrm{mg} \mathrm{kg}^{-1}$ is considered to be deficient (Radish et al., 1995). According to this limit value, the extractable $\mathrm{SO}_{4}{ }^{-2}-\mathrm{S}\left(2.40 \mathrm{mg} \mathrm{kg}^{-1}\right)$ concentration of our experiment soil appears to be deficient. In this case, $\mathrm{N}: \mathrm{S}$ ratio designated as 23.76 in $\mathrm{S}_{0} \mathrm{FYM}_{0}$ application is the indicator of the plant's facing with a deficiency in its sulphur nutrition and this will obviously cause negative effects in protein synthesis. However, by the increase of the sulphur applications, the imbalance of plant's N:S ratios disappeared and it seems to have a balance between nitrogen and sulphur elements which are highly important in protein synthesis. The uptake of sulphur, yield, quality and optimizing the $\mathrm{N}: \mathrm{S}$ ratio in plants were improved by sulphur fertilization (Skwierawska et al., 2016). But also while trying to maintain this balance, the risk of sulphur's increasing soil salinity should be kept in mind and it should be taken into consideration while doing sulphur fertilization especially on saline soils. A greenhouse survey study in Antalya/Turkey, it appears that there are imbalance for $\mathrm{N}: \mathrm{S}$ ratio, even if a sulphur deficiency is not determined in tomato leaves (Orman and Kaplan, 2009)

The effect of sulphur alone is found to be important on shoot dry weight. The dry weight was $22.28 \mathrm{~g} \mathrm{pot}^{-1}$ in $\mathrm{S}_{0}$ application whereas there became an increase about 17$22 \%$ by sulphur applications. The increase occurred was not due to the increase of sulphur level, the sulphur application doses statistically took place in the same group. Crusicol et al. (2006) indicated that sulphur fertilization has not considered by bean (Phaseolus vulgaris L.) growers. Whereas, the increase of grain yield can be limited by low levels of sulphur fertilization in common bean crops with high-input technology. Researchers reported that leaf S content, dry weight and grain yield of common bean is increased by sulphur fertilization. Kaplan and Orman (1998) reported an increase in dry weight of sorghum with sulphur applications.

\section{Conclusion}

The sulphur is an advisable material in order to decrease the soil $\mathrm{pH}$ on calcareous sandy loam and high $\mathrm{pH}$ soils and also to increase the uptake of the phosphorus element 
by plants of which the solubility in soil is significantly depending on $\mathrm{pH}$. But the risk of the sulphur's creating salinity in soil should be taken into consideration and this negative effect should be well managed especially on the agricultural lands under the risk of salinity. Also, Gulmezoglu et al. (2016) reported that salt application generally reduced the fresh and dry weights of green bean genotypes.

On the sulphur deficient soils, the sulphur or other sulphur fertilizers absolutely should be included on fertilization programmes to obtain sulphur for the plants that are in need of sulphur requirement such as bean. Because it has been determined that if the necessary sulphur applications are not done on such soils, a significant imbalance may emerge in $\mathrm{N}: \mathrm{S}$ ratio of the plant and the balance may be damaged against sulphur. When considering not only nitrogen but also sulphur as well is effective in protein formation in plants, this situation might have negative repercussions on high protein content plant's protein synthesis and quality such as bean.

According to the data obtained from this study, the applications of sulphur in $50 \mathrm{mg}$ $\mathrm{kg}^{-1}$ and $100 \mathrm{mg} \mathrm{kg}^{-1}$ levels to bean growing on a calcareous sandy loam soils which are deficient in organic matter and $\mathrm{SO}_{4}^{-2}$ are thought to be sufficient in terms of yield and quality. Consequently, the further studies are needed to optimize amount of sulphur addition for other soil types and plant species.

Acknowledgements. The authors would like to express their appreciation to The Scientific Studies Management Unit of Akdeniz University, Antalya, Turkey.

\section{REFERENCES}

[1] Anonymous (1982): The Fourth Major Nutrient. - Sulphur Institute, Washington, D.C.

[2] Barczak, B., Nowak, K. (2015): Effect of sulphur fertilisation on the content of macroelements and their ionic ratios in potato tubers. - Journal of Elementology 20(1): 37-47.

[3] Black, C. A. (1965): Methods of Soil Analysis, Part 2, p. 1372-1376. - Amer. Society of Agronomy Inc. Publisher, Madison, WI.

[4] Bouyoucos, G. J. (1955): A recalibration of hydrometer method for making mechanical analysis of the soils. - Agronomy Journal 4: 434.

[5] Brahim, S., Niess, A., Pflipsen, M., Neuhoff, D., Scherer, H.( 2017): Effect of combined fertilization with rock phosphate and elemental sulphur on yield and nutrient uptake of soybean. - Plant Soil Environ 63(2): 89-95.

[6] Crusciaol, C. A. C., Soratto, R. P., Silva, L. M., Lemos, L. B. (2006): Side dressing sulphur fertilization in common bean crop in no-tillage system. - Bragantia 65(3): 459465 .

[7] Fox, R. L., Olson, R. A., Rhoades, H. F. (1964): Evaluating the sulfur status of soils by plants and soil tests. - Soil Science Society of America Proceedings 28: 243-246.

[8] Gaines, T. P., Phatak, S. C. (1982): Sulfur fertilization effects on the constancy of the protein N:S ratio in low and high sulphur accumulating crops. - Agronomy Journal 74: 415-418.

[9] Gulmezoglu, N., Aydogan, C., Turhan, E. (2016): Physiological, biochemical and mineral dimensions of green bean genotypes depending on $\mathrm{Zn}$ priming and salinity. - Legume Research 39(5): 713-721

[10] Kacar, B. (2009): Soil Analysis. - Nobel Publications, Ankara (in Turkish).

[11] Kacar, B., Inal, A. (2008): Plant Analysis. - Nobel Publications, Ankara (in Turkish). 
[12] Kacar, B., Katkat, A. V. (2007): Plant Nutrition. - Nobel Publications, Ankara (in Turkish).

[13] Kaplan, M., Orman, Ş. (1998): Elemental sulphur and sulphur containing waste in a calcareous soil in Turkey. - Journal of Plant Nutrition 21(8): 1655-1665.

[14] Modaish, A. S., Al-Mustafa, W. A., Metwally, A. I. (1989): Effect of elemental sulphur on chemical changes and nutrient availability in calcareous soil. - Plant and Soil 116: 95101.

[15] Olsen, S. R., Sommers, E. L. (1982): Phosphorus Soluble in Sodium Bicarbonate. - In: Page, A. L., Miller, R. H., Keeney, D. R. (eds.) Methods of Soil Analysis. Part 2, Chemical and Microbiological Properties, pp. 404-430. American Society of Agronomy, Inc., Soil Science Society of America, Inc. Publisher, Madison, WI.

[16] Orman, Ş., Kaplan, M. (2009): Determination of sulphur contents in tomato grown in greenhouses in West Mediterranean Region, Turkey. - Asian Journal of Chemistry 21(1): 484-489.

[17] Orman, Ş., Kaplan, M. (2011): Effects of elemental sulphur and farmyard manure on pH and salinity of calcareous sandy loam sand some nutrient elements in tomato plant. Journal of Agricultural Science and Technology 5(1): 20-26.

[18] Orman, Ş., Ok, H. (2012): Effects of sulphur and zinc applications on growth and nutrition of bread wheat in calcareous clay loam soil. - African Journal of Biotechnology 11(13): 3080-3086.

[19] Radish, M., Ishaq, M., Saeed, M. (1995): Sulphur status of soils and plants in Punjab Province of Pakistan. - Sulphur in Agriculture 19: 48-53.

[20] Reuther, D. J., Robinson, B. J. (1998): Plant analysis. An interpretation manual (P. Mader, P. Tlustos). - Biologia Plantarum 41(2): 317-318.

[21] Schung, E. (1990): Sulphur nutrition quality of vegetables. - Sulphur in Agriculture 14: 2-7.

[22] Skwierawska, M., Benedycka, Z., Jankowski, K., Skwierawski, A. (2016): Sulphur as a fertiliser component determining crop yield and quality. - Journal of Elementology 21(2): 609-623.

[23] Stewart, B. A., Porter, L. K. (1969): Nitrogen-sulfur relationships in wheat (Triticum aestivum L.), corn (Zea mays), and beans (Phaseolus vulgaris). - Agronomy Journal 61: 267-271.

[24] Tiecher, T., dos Santos, D. R., Rasche, J. W. A., Brunetto, G., Mallmann, F. J. K., Piccin, R. (2012): Crop responses and sulphur availability in soils with different contents of clay and organic matter submitted to sulfate fertilization. - Bragantia 71(4): 518-527.

[25] Tiwari, R. C. (1995): Soil sulphur status and crop responses to sulphur application in Eastern Uttar Pradesh, India. - Sulphur in Agriculture 19: 21-25.

[26] Tiwari K. N., Tiwari A., Sharma, H. L., Dagur, B. S. (1997): Soil S status and crop response to $S$ applications in Uttar Pradesh, India. - Sulphur in Agriculture 20: 60-70. 